\title{
CAN NATURA 2000 MAPPING BE USED TO ZONE THE ŠUMAVA NATIONAL PARK?
}

\author{
JAROMÍR BLÁHA ${ }^{1, *}$, DUŠAN ROMPORTL², and ZDENKA KŘENOVÁ ${ }^{3,4,5}$ \\ ${ }^{1}$ Hnutí DUHA - Friends of the Earth Czech Republic, Lublaňská 18, 12000 Prague 2, Czech Republic \\ 2 Department of Physical Geography and Geoecology, Faculty of Science, Charles University in Prague, Albertov 6, 12843 Prague 2, \\ Czech Republic \\ ${ }^{3}$ Global Change Research Centre AS CR, Department of Biodiversity Research, Na Sádkách 7, 37005 České Budějovice, \\ Czech Republic \\ ${ }^{4}$ Institute of Environmental Studies, Faculty of Science, Charles University in Prague, Benátská 2, 12801 Prague 2, Czech Republic \\ ${ }^{5}$ Faculty of Science, University of South Bohemia, Branišovská 31, 37005 České Budějovice, Czech Republic \\ * Corresponding author: jaromir.blaha@hnutiduha.cz
}

\section{ABSTRACT}

The future of the Šumava National Park is linked to discussions on its zoning, which has undergone significant changes since the establishment of the Park. The present zonation was strongly criticized by experts, representatives of NGOs and international organizations. Over the last couple of years, politicians became more vocal in callings for a new law that would fix the rules governing the use of the Šumava NP and the central question in this is zonation. A new proposal on the zonation was prepared by the scientific community, but in order to maximize the probability of its acceptance, the area of the core zone proposed was just barely sufficient to include the most valuable parts of the most important habitats and some of the habitats of the most important species. Thus, any further reduction in the area of the core zone is likely to pose a serious threat to the survival of important species and habitats occurring in the Šumava NP. Here we present a politically unbiased estimate of the optimum size of the core zone based on Natura 2000 habitats and species mapping.

Keywords: zonation, management of national park, biodiversity, Natura 2000, GIS

\section{Introduction}

The Bohemian Forest (Šumava Mts. in Czech) is a mountain ridge along the Czech-Bavarian border in the heart of Europe. This densely wooded landscape, comprising crystal clear mountain streams, unspoilt marshlands, mires and bog woodlands, and abandoned mountain pastures at high altitudes, is a refuge for many endangered species of plants and animals. Elements of northern boreal forest represented here include capercaillie (Tetrao urogallus), Ural owl (Strix uralensis) and three-toed woodpecker (Picoides tridactylus). This transboundary area is also home to several iconic species, such as lynx (Lynx lynx), moose (Alces alces), peregrine (Falco peregrinus) and freshwater pearl mussel (Margaritifera margaritifera), each of which now occurs only in few viable populations in Central Europe. Nature is protected here in two national parks (Fig. 1): the Bayerischer Wald NP (Germany; established 1969 and enlarged in 1997 to 24,250 ha) and the Šumava NP (Czech Republic; established 1991; 68,064 ha). They constitute the largest cross-border protected area in Central Europe (Křenová and Kiener 2012). Each component is the largest terrestrial Natura 2000 site in the respective countries and a significant part of the Natura 2000 network, which was established to protect the most endangered habitats and species in Europe, as defined in the 1992 Habitats Directive and 1979 Birds Directive.

Formally, the Natura 2000 network recognizes Sites of Community Importance (SCI), in terms of 231 habitat types and 911 animal and plant species defined in the Habitats Directive, and Special Protection Areas (SPA), in terms of 194 species of bird defined in the Bird Directive (Sunseth and Creed 2010). The SCI Šumava, the largest in the Czech Republic, was designated by Government Order No. 132/2005. It is a unique mosaic of natural and secondary habitats of exceptional natural value of European-wide significance. Each type of habitat hosts numerous rare and protected plant and animal species. The SAC Šumava was designated by Government Order No. 681/2004 on December 8, 2004. Among the many species in Annex I of the Birds Directive that occur here, the most notable are three species of grouse, especially capercaillie (Tetrao urogallus). Among the handful of populations of capercaillie still persisting in highland ecosystems in Central Europe, the population in the Bohemian Forest now represents the only viable one in the Czech Republic.

For a long time now the debates about the future of nature conservation in the Šumava NP have involved discussions on the zoning of the Park, which has undergone significant changes since its establishment (Křenová and Hruška 2012). When the NP was founded in 1991, its zonation was based on internationally accepted concepts. Change in the leadership of the national park in 1995 brought about a change in management. Zone I, the most valuable and strictly protected part of the NP (equivalent to the core zone under Czech legislation), was reduced in size and the original 54 units were further fragmented into 135 smaller units. The main reason for this was a strong desire for active management, mainly logging of bark beetle-infested trees. This was strongly criticized by experts, representatives of NGOs and international organizations (IUCN, Ramsar Committee). 
During 2004-2005, a new zonation was proposed by scientists and Šumava NP Authorities, which included the recommendations of experts, but unfortunately was not officially approved, because of opposition from local communities and politicians. During the last couple of years, politicians became more vocal in calling for a new law that would fix the rules governing the use of the Šumava NP and the central question in this is the zonation of the Park.

A new proposal for the zonation of the Park was prepared by a scientific committee (Křenová and Hruška 2012) and submitted to the Ministry of Environment. This proposal took into account the current condition of the Sumava ecosystems, the latest knowledge and understanding of their dynamics, and the effects of natural disturbances. A special emphasis was placed on the population dynamics and ecological requirements of flagship species, such as capercaillie. To maximize the probability of acceptance of this proposal by the politicians, the strictly protected Zone I is only just large enough to include the most valuable parts of the most important habitats and some of the locations where the most important species occur. Thus, the scientific proposal is the minimum acceptable as any further reduction in Zone I is likely to seriously threaten the survival of certain important species and habitats in the Sumava NP. However, we feel that the scientific community should be aware that it is possible to arrive at a politically unbiased proposal, which defines the optimum size of the core zone of the Šumava NP and does not pander to the views of local politicians. Here we present such a proposal, which is based on data from Natura 2000 habitats and species mapping.

\section{Methods}

\section{Natura 2000 data}

Mapping of habitats organized by the Nature Conservation Agency of the Czech Republic (NCA) and that of important bird areas, organized by the NCA in cooperation with the Czech Ornithological Society, the Czech partner of the Bird Life International, is an extensive and ambitious project set up as part of the Natura 2000 network in this country (Hartel et al. 2009). Pilot habitat mapping was carried out in 2000. Mapping was carried out during 2001-2004 at two levels: detailed mapping focused on areas with an abundant occurrence of natural habitats and selective mapping (contextual mapping) in the rest of the country. In addition to the indication of a habitat on a map, data on its representativeness, conservation status and other characteristics were also recorded. More details are available on the methodology of habitat mapping in Guth (2002). The Šumava NP Headquarters was deeply involved in the preparation of the Natura 2000 network. There was also a bilateral project with the Bayerischer Forest NP, which resulted in the publication of a trans-boundary map of Natura 2000 habitats and species locations (Hußlein and Kiener 2007), and joint discussions on the appropriate management practices for Natura 2000 sites (Hußlein et al. 2009).

SCI Sumava $(171,959 \mathrm{ha})$ is the largest SCI in the Czech Republic and includes the whole of the Sumava NP, parts of the Šumava Protected Landscape Area and the Šumava Biosphere Reserve. Because of its great importance for nature conservation the whole of the Sumava NP was mapped in detail. The habitat mapping followed the methodology of Chytrý et al. (2001) and was carried out by botanists. Digitized data from this mapping project was used to define the area in terms of the Natura 2000 network (natural habitat types) and in the management of this protected area. Nineteen habitats in the Annex I and ten species in Annex II of the Habitats Directive are protected in the Šumava NP (Table 1). The most valuable habitats include the well-preserved complex of peat and wetland habitats, primeval forests and species-rich secondary mountain grasslands.

It is known that non-intervention management of protected areas and large Natura 2000 sites significantly improves habitat quality and living conditions for species depending on natural dynamic processes (e.g. all primary forest habitats in Central Europe) and therefore provides a substantial contribution to maintaining current levels of biodiversity (Müller et al. 2008; Lehnert et al. 2013). Non-intervention management should thus focus mainly on primary habitats and large areas with the capacity of self-restoration (Hußlein et al. 2009).

Therefore, the following four habitats protected in SCI Sumava were selected as basic components of the non-intervention parts of Zone I in the Šmava NP:

1. spruce forests (L9.1 Montane Calamagrostis spruce forests, L9.2A Bog spruce forests, L9.2B Water logged spruce forests, L9.3 Montane Athyrium spruce forests),

2. beech forests (L5.1 Herb-rich beech forests, L5.4 Acidophilous beech forests),

3. raised bogs, springs, fens and transitional mires ( $\mathrm{R} 2.2$ Acidic moss-rich fens, R2.3 Transitional mires, R3.1 Open raised bogs, R3.2 Raised bogs with Pinus mugo, R3.3 Bog hollows),

4. other valuable NATURA 2000 habitats - usually mosaics of the following habitats: A4.2 Subalpine tall-forb vegetation, A4.3 Subalpine tall-fern vegetation, L2.1 Montane grey alder galleries, L2.2 Ash-alder alluvial forests, L4 Ravine forests, L10.1 Birch mire forests, L10.2 Pine mire forests with Vaccinium and L10.4 Pinus rotundata bog forests which occur usually in mosaic with other spruce or beech habitats mentioned above. Other habitats such as V1 Macrophyte vegetation of naturally eutrophic and mesotrophic still waters occur in/along several rivers in NP. Last group of valuable habitats is represented by semi-natural meadows and pastures, which consist of T1.2 Montane Trisetum meadows, T1.6 Wet Filipendula grasslands, T1.9 
Table 1 Habitats and species which are subject to protection in SAC and SCI Šumava. Priority habitats and species are marked by *.

\begin{tabular}{|c|c|c|c|}
\hline Code & Habitats of Annex I of Habitat Directives & (ha) & $\begin{array}{l}\text { Biotop units for mapping } \\
\text { (see Chytrý et al. 2001) }\end{array}$ \\
\hline 3130 & $\begin{array}{l}\text { Oligotrophic to mesotrophic standing waters with vegetation } \\
\text { of the Littorelletea uniflorae and/or of the Isoëto-Nanojuncetea }\end{array}$ & 27.38 & $\begin{array}{l}\text { M2.2 - Annual vegetation on wet sands } \\
\text { M3 - Vegetation of perennial amphibious herbs } \\
\text { V6 - Isöetes vegetation }\end{array}$ \\
\hline 3150 & $\begin{array}{l}\text { Natural eutrophic lakes with Magnopotamion or } \\
\text { Hydrocharition - type vegetation }\end{array}$ & 16.98 & $\begin{array}{l}\text { V1 - Macrophyte vegetation of naturally eutrophic } \\
\text { and mesotrophic still waters }\end{array}$ \\
\hline 3260 & $\begin{array}{l}\text { Water courses of plain to montane levels with the Ranunculion } \\
\text { fluitantis and Callitricho-Batrachion vegetation }\end{array}$ & 81.99 & $\begin{array}{l}\text { V4A - Macrophyte vegetation of water streams with } \\
\text { currently present aquatic macrophytes }\end{array}$ \\
\hline 4030 & European dry heaths & 84.48 & $\begin{array}{l}\text { T8.2B - Secondary submontane and montane } \\
\text { heaths without Juniperus communis }\end{array}$ \\
\hline 5130 & Juniperus communis formations on heaths or calcareous grasslands & 5.07 & $\begin{array}{l}\text { T8.2A - Secondary submontane and montane } \\
\text { heaths with Juniperus communis }\end{array}$ \\
\hline $6230^{*}$ & $\begin{array}{l}\text { Species-rich Nardus grasslands, on siliceous substrates in mountain } \\
\text { areas (and submountain areas, in Continental Europe) }\end{array}$ & 1066.89 & $\begin{array}{l}\text { T2.1 - Subalpine Nardus meadows } \\
\text { T2.3B - Submontane or montane Nardus meadows } \\
\text { without Juniperus communis }\end{array}$ \\
\hline 6410 & $\begin{array}{l}\text { Molinia meadows on calcareous, peaty or clayey-siltladen soils } \\
\text { (Molinion caeruleae) }\end{array}$ & 221.66 & T1.9 - Intermittently wet Molinia meadows \\
\hline 6430 & $\begin{array}{l}\text { Hydrophilous tall herb fringe communities of plains and of the } \\
\text { montane to alpine levels }\end{array}$ & 545.13 & $\begin{array}{l}\text { A4.2 - Subalpine tall-forb vegetation } \\
\text { A4.3 - Subalpine tall-fern vegetation } \\
\text { T1.6 - Wet Filipendula grasslands }\end{array}$ \\
\hline 6510 & Lowland hay meadows (Alopecurus pratensis, Sanguisorba officinalis) & 579.06 & T1.1 - Mesic Arrhenatherum meadows \\
\hline 6520 & Mountain hay meadows & 2997.42 & T1.2 - Montane Trisetum meadows \\
\hline $7110^{*}$ & Active raised bogs & 383.86 & $\begin{array}{l}\text { R3.1 - Open rised bogs } \\
\text { R3.3 - Bog hollows }\end{array}$ \\
\hline 7140 & Transition mires and quaking bogs & 1255.29 & $\begin{array}{l}\text { R2.2 - Acidic moss-rich fens } \\
\text { R2.3 - Transition mires }\end{array}$ \\
\hline 8220 & Siliceous rocky slopes with chasmophytic vegetation & 167.83 & $\begin{array}{l}\text { S1.2-Chasmophytic vegetation of siliceous cliffs } \\
\text { and boulder screes } \\
\text { A6B - Acidophilous vegetation of alpine cliffs }\end{array}$ \\
\hline 9110 & Luzulo-Fagetum beech forests & 15966.51 & L5.4 - Acidophilous beech forests \\
\hline 9130 & Asperulo-Fagetum beech forests & 2092.32 & L5.1 - Herb-rich beech forests \\
\hline $9180^{*}$ & Tilio-Acerion forests of slopes, screes and ravines & 136.76 & L4 - Ravine forests \\
\hline 91D0* & Bog woodland & 3566.74 & $\begin{array}{l}\text { L9.2A - Bog spruce forests } \\
\text { L10.1 - Birch mire forests } \\
\text { L10.2 - Pine mire forests with Vaccinium } \\
\text { L10.4 - Pinus rotundata bog forests } \\
\text { R3.2 - Raised bogs with Pinus mugo }\end{array}$ \\
\hline 91E0* & $\begin{array}{l}\text { Alluvial forests with Alnus glutinosa and Fraxinus excelsior } \\
\text { (Alno-Padion, Alnion incanae, Salicion albae) }\end{array}$ & 582.22 & $\begin{array}{l}\text { L2.1 - Montane grey alder galleries } \\
\text { L2.2 - Ash-alder alluvial forest }\end{array}$ \\
\hline 9410 & $\begin{array}{l}\text { Acidophilous Picea forests of the montane to alpine levels } \\
\text { (Vaccinio-Piceetea) }\end{array}$ & 18567.31 & $\begin{array}{l}\text { L9.1 - Montane Calamagrostis spruce forests } \\
\text { L9.2B - Waterlogged spruce forests } \\
\text { L9.3 - Montane Anthyrium spruce forests }\end{array}$ \\
\hline
\end{tabular}

\begin{tabular}{|l|l|}
\hline & \multicolumn{1}{|c|}{ Species of Annex II of the Habitat Directive } \\
\hline 1096 & Lampetra planeri \\
\hline 1324 & Myotis myotis \\
\hline 1029 & Margaritifera margaritifera \\
\hline 1361 & Lynx lynx \\
\hline $1914^{*}$ & Carabus menetriesi pacholei \\
\hline 1163 & Cottus gobio \\
\hline 1303 & Rhinolophus hipposideros \\
\hline 1355 & Lutra lutra \\
\hline $4094^{*}$ & Gentianella bohemica \\
\hline 1393 & Drepanocladus vernicosus \\
\hline
\end{tabular}




\begin{tabular}{|l|l|}
\hline & \multicolumn{1}{|c|}{ Species of Annex I of the Bird Directive } \\
\hline & Ciconia nigra \\
\hline & Dryocopus martius \\
\hline & Crex crex \\
\hline & Picoides tridactylus \\
\hline & Bonasa bonasia \\
\hline & Glaucidium passerinum \\
\hline & Aegolius funereus \\
\hline & Tetrao urogallus \\
\hline & Tetrao tetrix \\
\hline
\end{tabular}

Intermittently wet Molinia meadows, T2.1 Subalpine Nardus grasslands, T2.3B Submontane and montane Nardus grasslands, and finally T8.2A Secondary submontane and montane heaths.

Of course, some secondary habitats (e.g. orchid meadows) or small and fragmented areas need intervention. These, if of sufficient conservation importance, were included as managed parts of Zone I.

SAC Šumava (97,493 ha) hosts a total of 27 species listed in Annex I of the Birds Directive, 9 of which are protected here (Chvátal 2009; Table 1). Of the three grouse species occurring here, the most endangered is capercaillie (Tetrao urogallus). Its core areas were therefore included as the fifth component.

The data from the Natura 2000 mapping includes the five important components of Zone I. Four of them were particular habitats and the fifth the core areas for capercaillie, the most important species in this region. The sixth component was river canyons with unregulated mountain rivers, representing a specific phenomenon in this Park's landscape. There are no unique Natura 2000 habitats in the river canyons, but important species, like lynx, otter and peregrine occur there. Of course, non-intervention is the best management for such areas.

\section{GIS analyses}

All habitat and environmental data mentioned above were expressed digitally and handled in the GIS environment (ESRI ArcGIS 10.1). The proposed zonation was obtained in two steps: (i) overlay and synthesis of individual components and (ii) generalization of final output.

Initially, all components were analyzed separately in order to calculate their total area or number of patches, level of fragmentation and the percentage of the NP area they cover. After that, overlay and intersection of all the components was determined and the key habitats delineated. The crucial step was generalization of this mask, which was done using expert knowledge supported by topographical and forestry maps and aerial photographs. Forest management differs markedly within and outside the NP and so does the ownership of forests. Therefore, a $500 \mathrm{~m}$ wide buffer zone along the interior boundary of the NP was delineated in order to protect private for- ests in the vicinity against bark beetle attacks from the non-intervention zone. This width is supposed to be sufficient because bark beetle attacks trees less than $500 \mathrm{~m}$ from the source tree (Kautz et al. 2011). Because of the trans-boundary contracts that govern the management of forests along the Czech-Austrian border, a $200 \mathrm{~m}$ wide actively managed buffer strip (debarking of standing trees rather than logging) was proposed. No buffer zone was proposed along the border with the NP Bayerischer Wald, where non-intervention management is applied.

Then the following corrections and local expert knowledge were incorporated in order to improve the proposal that resulted from the above analysis:

1. adjacent units in Zone I were merged if they were separated by natural habitats;

2. forests in non-intervention parts of Zone I were extended, if applicable, to include spontaneous succession forests of mixed age structure (20-70 years old) occurring in former military training areas or abandoned fields;

3. important stands of silver fir (Abies alba) were added to Zone I;

4. important mating areas of black grouse (Tetrao tetrix), species protected in SAC Šumava, were added to Zone I. Although black grouse is not a typical species of non-intervention areas, nevertheless it is extremely sensitive to disturbance by human activities;

5. buffer zones around villages were excluded from Zone I regardless of whether or not Natura 2000 habitats occur there;

6. the border of Zone I was straightened and made to follow as far as possible natural or easily visible lines (streams, roads, etc.).

\section{Results}

The component spruce forests, which combines data from four biotopes (L9.1 Montane Calamagrostis spruce forests, L9.2A Bog spruce forests, L9.2B Water logged spruce forests, L9.3 Montane Athyrium spruce forests), is shown in Fig. 2 and covers an area of $160 \mathrm{~km}^{2}$. The breeding areas of many birds, including species protected in the SAC Šumava like the three-toed woodpecker ( $P i$ - 


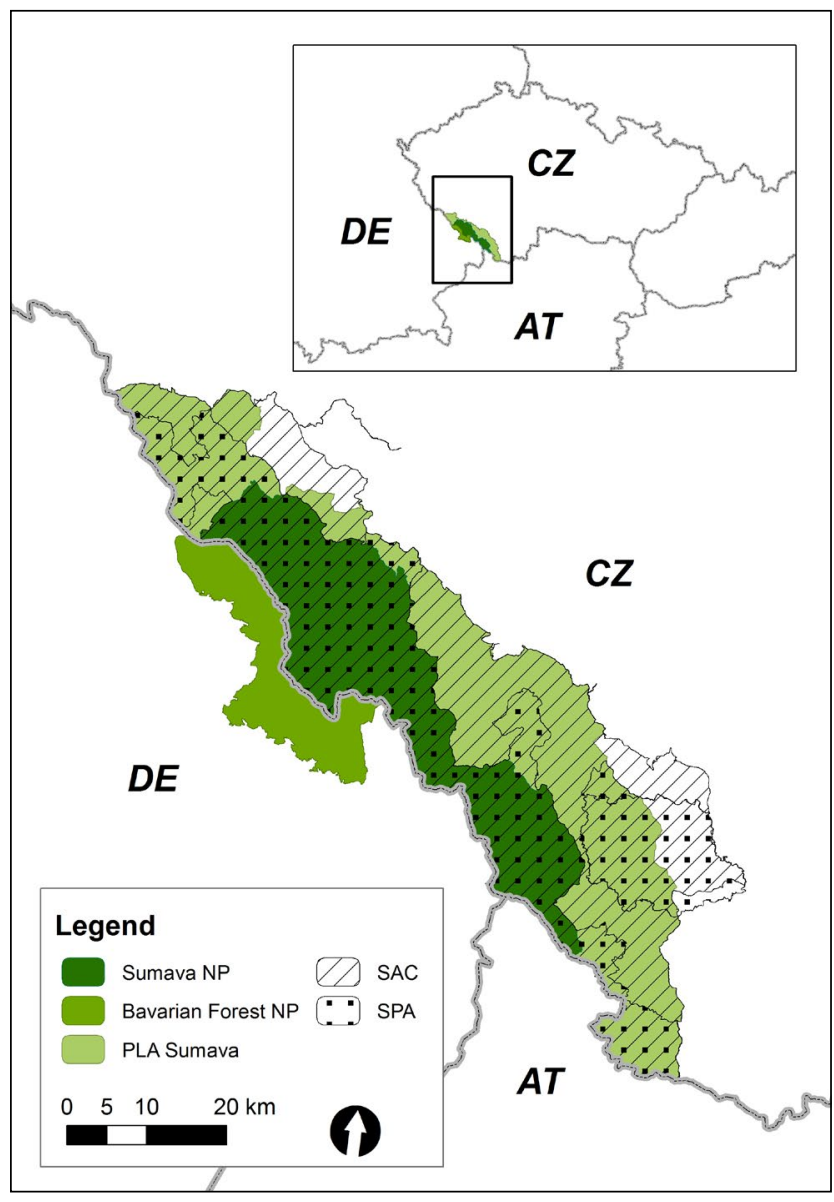

Fig. 1 Map of the Šumava National Park, Protected Landscape Area Šumava, SAC Šumava, SCI Šumava in the Czech Republic and the National Park Bayerischer Wald in Germany.

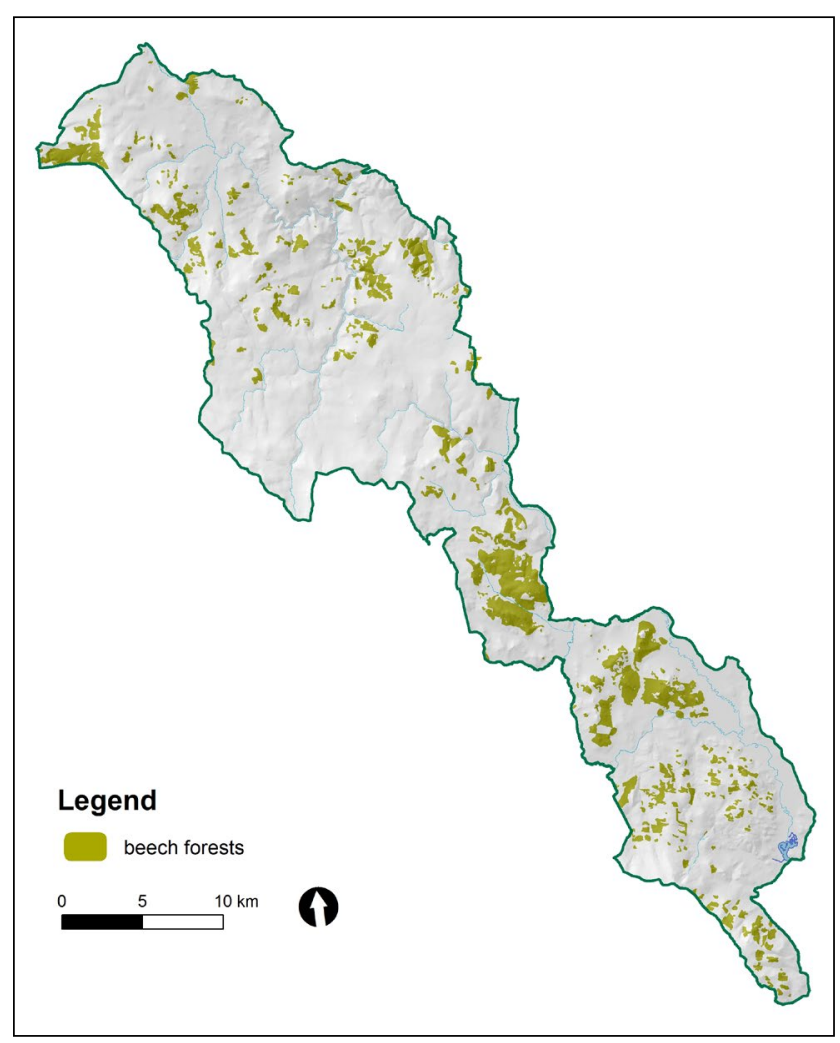

Fig. 3 Distribution of beech forests within the Šumava NP.

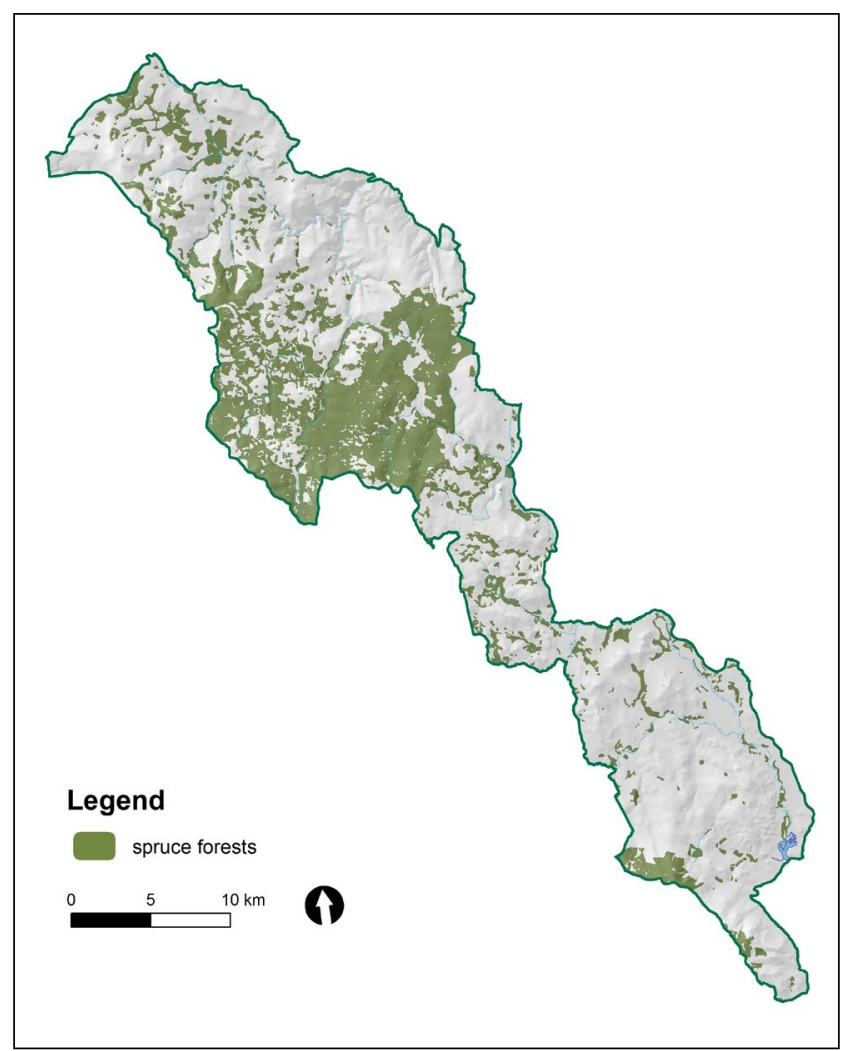

Fig. 2 Distribution of spruce forests within the Šumava NP.

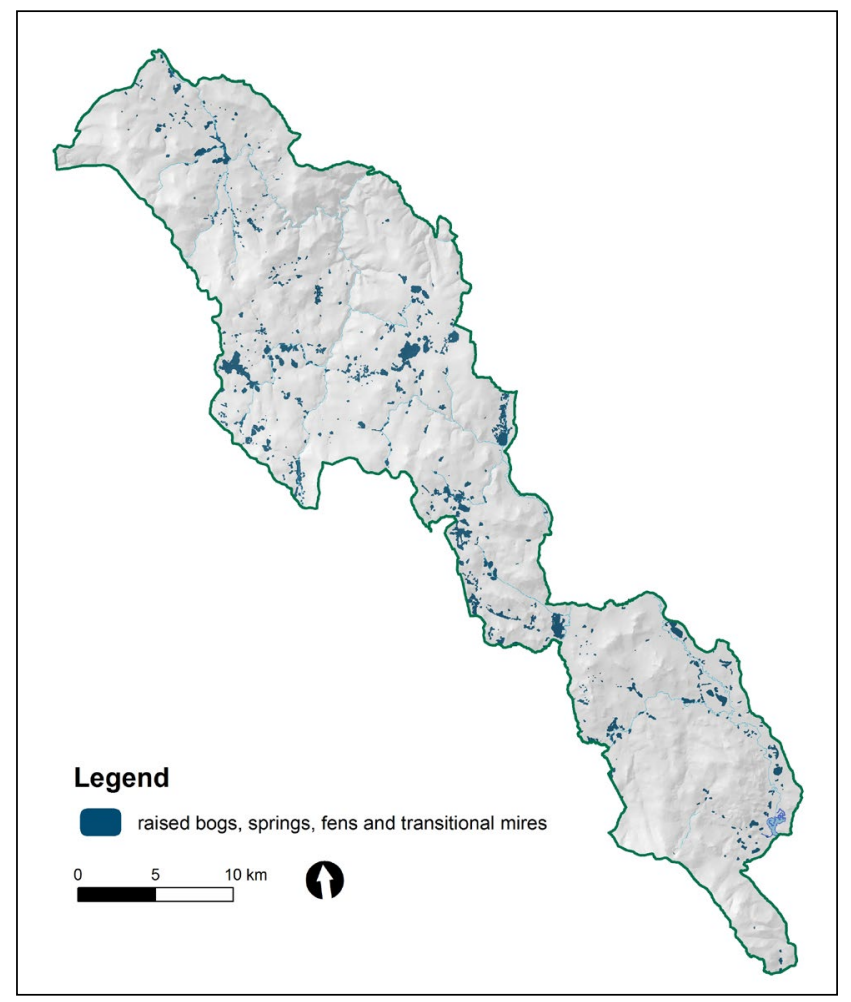

Fig. 4 Distribution of raised bogs, springs, fens and transitional mires within the Šumava NP. 


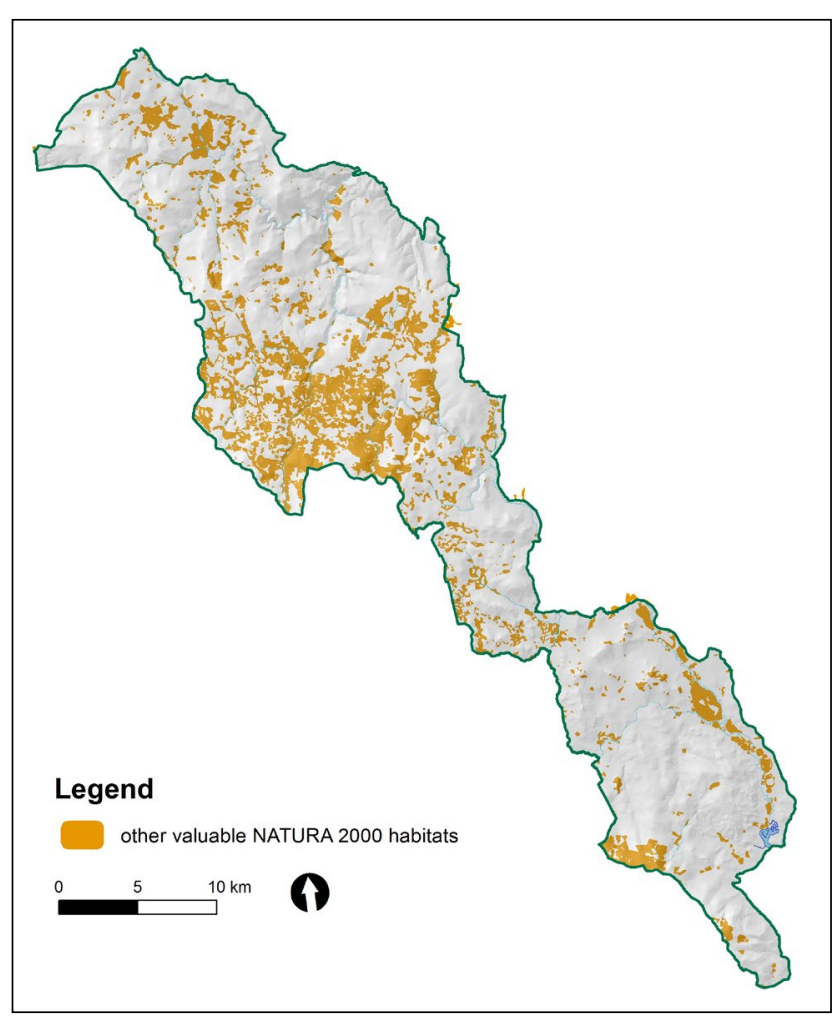

Fig. 5 Distribution of other valuable Natura 2000 biotopes within the Šumava NP.

coides tridactylus), pygmy owl (Glaucidium passerinum) and tengmalm's owl (Aegolius funereus) mainly occur in this component.

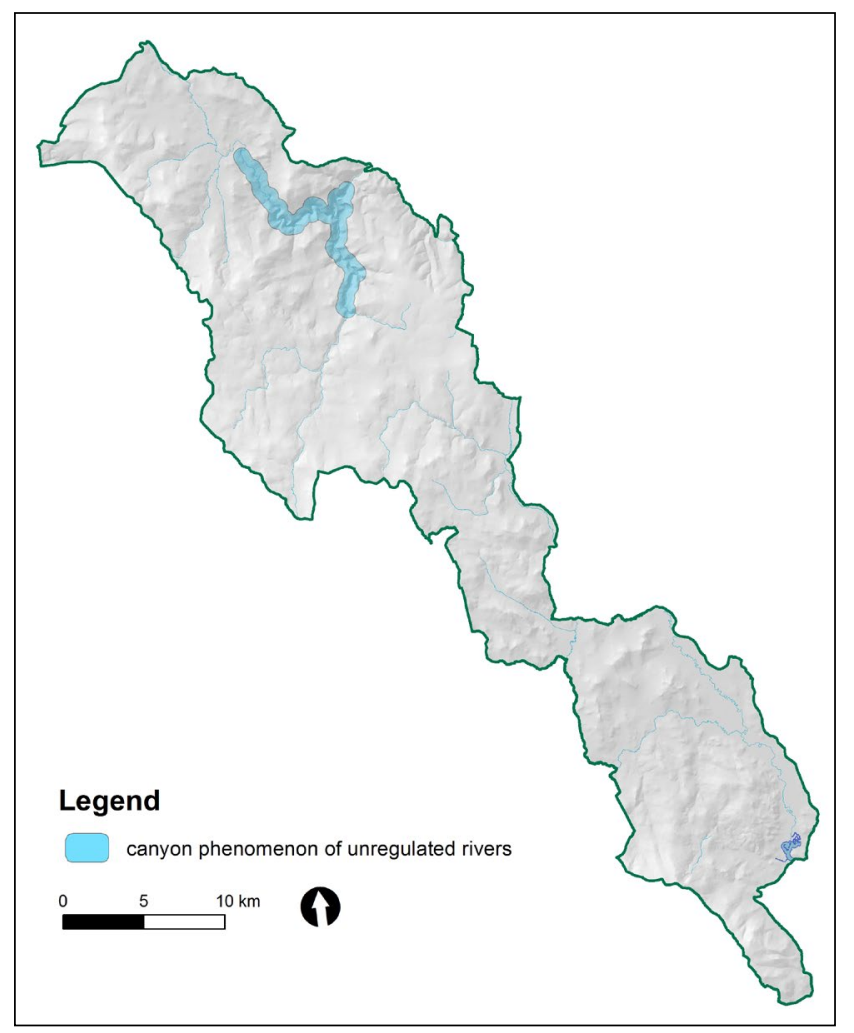

Fig. 7 River canyons phenomenon within the Šumava NP.

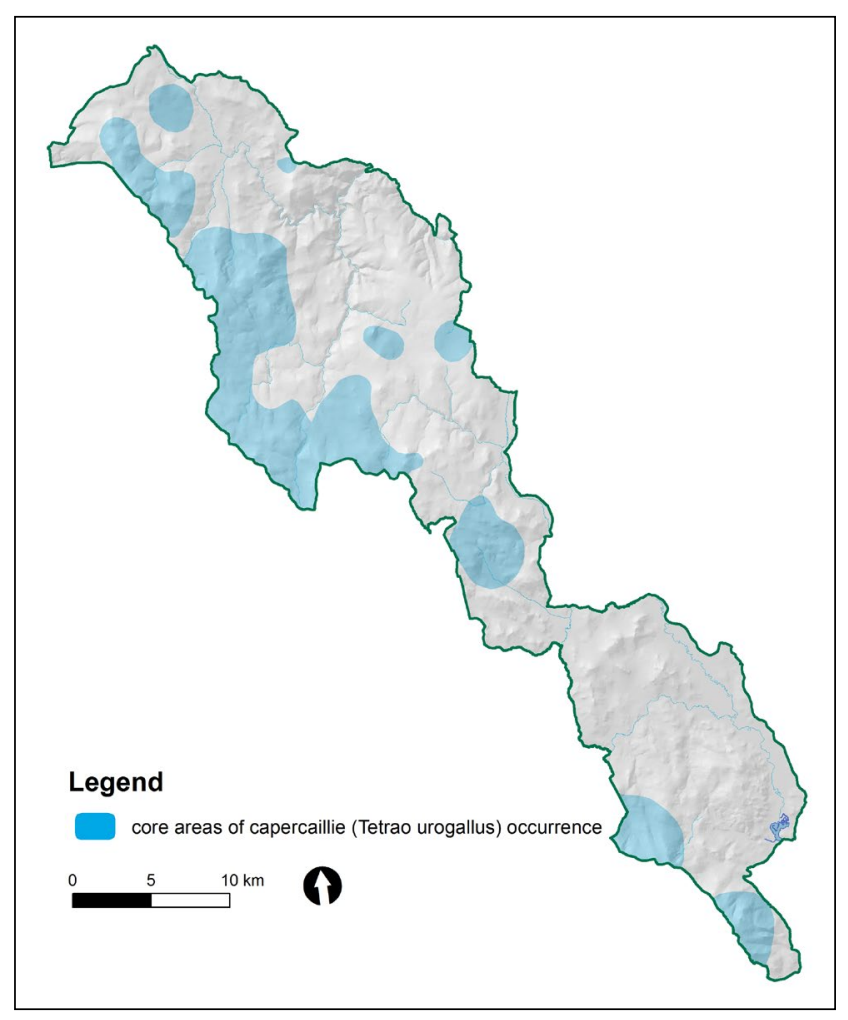

Fig. 6 Core areas of capercaillie (Tetrao urogallus) occurrence.

Beech forests component (Fig. 3), which combines data from two biotopes (L5.1 Herb-rich beech forests, L5.4 Acidophilous beech forests) and covers an area of $63 \mathrm{~km}^{2}$. Only the most representative segments with an age structure RP or Q are considered here. Beech forests are habitats of the protected black stork (Ciconia nigra), Ural owl (Strix uralensis), and many other species.

The component for raised bogs, springs, fens and transitional mires (Fig. 4) combines data from five biotopes (R2.2 Acidic moss-rich fens, R2.3 Transitional mires, R3.1 Open raised bogs, R3.2 Raised bogs with Pinus mugo, R3.3 Bog hollows) and covers $21 \mathrm{~km}^{2}$. This area is also an important habitat of many endangered plants and invertebrates. Among many others also Carabus menetriesi, which is protected in the SCI Šumava, occurs there.

The last habitat component combines data on other valuable Natura 2000 biotopes and their mosaics and covers the area of $97 \mathrm{~km}^{2}$ (Fig. 5). Nardus meadows and other secondary grasslands, many of them with blocked or very slow succession, are important biodiversity hotspots in the region, which is mostly covered by forests.

The fifth layer is showing the core areas of capercaillie (Tetrao urogallus) occurrence and covers $183 \mathrm{~km}^{2}$. Five large and four smaller core areas (Fig. 6) were defined according to population monitoring held by NP Administration and Czech Ornithological Society, delineation was consulted with local experts as well.

The sixth layer (Fig. 7) shows river canyons phenomenon - the Křemelná River, the Otava River and 

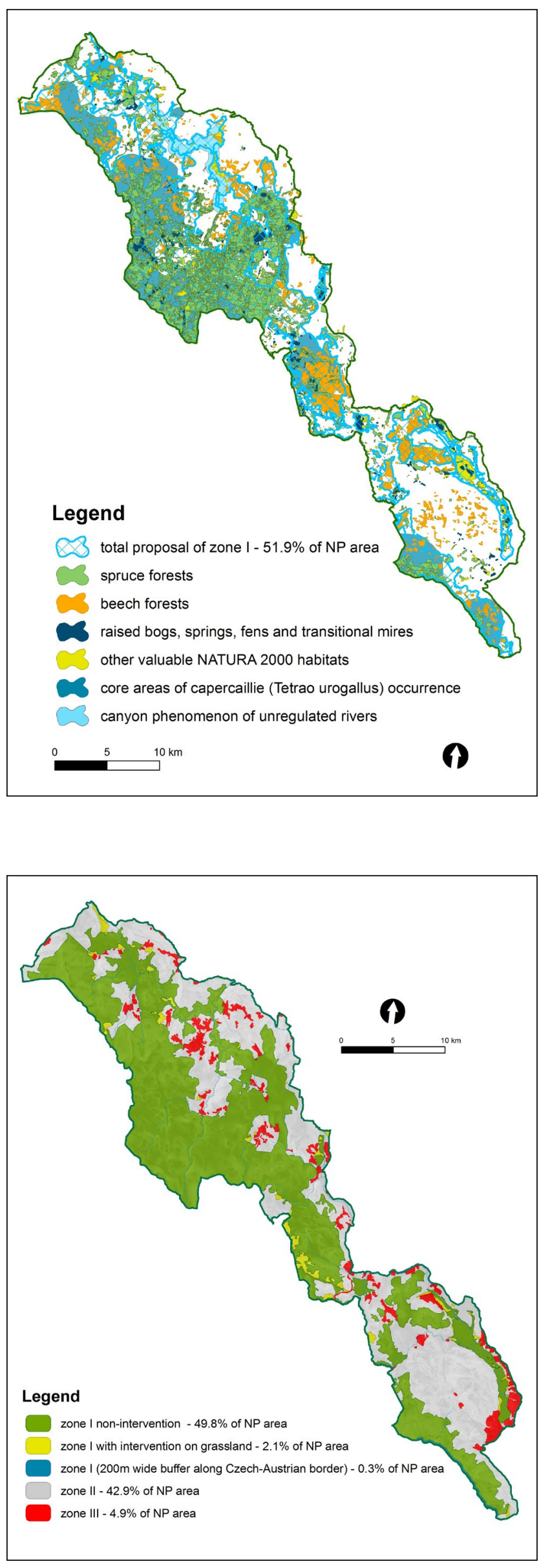

Fig. 8 The proposal of new zonation for the Šumava NP. the Vydra River canyons. The important species like the lynx (Lynx lynx), otter (Lutra lutra) or peregrine (Falco peregrine), which are sensitive to human-caused disturbances, live in these canyons. Bullheads (Cottus gobio), a species protected in the SCI Šumava, is common there.

The final proposal is presented in Fig. 8 in which $49.8 \%$ of the area of the Šmmava NP that is not managed and $2.1 \%$ of the permanently managed secondary grassland are included in Zone I. Zone III remains as it is (4.9\%) and contains built-up and potentially built-up areas according to Act No. 183/2006 Coll. Planning and Building Regulations. Zone II includes the remaining $42.9 \%$.

\section{Discussion}

The current zonation of the Šumava NP was criticized because the core zone (Zone I in Czech legislation) is extremely fragmented (135 units) and very small being only $13 \%$ of the area of the Šumava NP (Šolar and Galland 2002). Therefore, it is essential to establish a new system zonation. Several proposals were suggested recently. All of them define almost identical core zones. The recently published scientific proposal (Křenová and Hruška 2012) assumes that both the quality of the conditions and potential for natural development in the Šumava NP are high. They propose that Zone I includes $39.2 \%$ of the area of the Šumava NP (18,233 ha of forest plus 1,202 ha of grassland) and published biological arguments for including 15 main units in Zone I. However, this proposal, submitted to the Ministry of Environment, is the very minimum of what is required.

In this paper we present a more generous proposal of Zone I that should include $52.2 \%$ of the Šumava NP. The 15 units proposed by Křenová and Hruška (2012) are now included in larger units, mainly composed of spruce forests or beech forests generated by the Natura 2000 mapping data.

Since 1995, when the current Šumava NP zonation was implemented, most of the forest ecosystems were intensively managed and fragmented mainly due to the logging of trees attacked by bark-beetle. As a result, the stability of the forest in terms of the ability of the trees to withstand the damaging effects of high winds decreased and large areas of the Šumava NP forest were badly damaged by the windstorm Kyrill in January 2007. Natura 2000 habitats were used at that time to define the non-intervention areas (Křenová 2008), especially those habitats that thrive well without human intervention (montane spruce forests, peat bogs etc.). As a result, a non-intervention management policy was planned in 2007 in almost $30 \%$ of the Šumava NP area: in the whole of Zone I and certain parts of Zone II, especially in mountain spruce forests at high altitudes and water logged spruce forests.

Non-intervention management is not suitable for secondary habitats or small and fragmented areas. Therefore, this approach should focus mainly on primary hab- 
itats and large areas capable of self-restoration (Hußlein et al. 2009). Experience in other EU countries shows (EC 2012) that at large Natura 2000 sites the appropriate management is a combination of non-intervention management of primary habitats with permanent management of small patches of secondary habitat (e.g. secondary grasslands, juniper pastures). This is the approach used in the Bayerischer Forest NP (Kiener et al. 2008).

We show that data from the Natura 2000 mapping project can be used to define the optimum pattern of zonation for the Šumava NP while including other habitats like river canyons and the locations for particular species and taking into consideration the limitations imposed (e.g. by international agreements, buffer zones) and local knowledge of the area.

We believe that the Sumava NP and other large protected areas in Europe include excellent examples of particular natural habitats and can be used for determining the effects of natural disturbance and climate change. Long-term management strategies and good zonation are essential tools for this task.

\section{Acknowledgements}

The authors wish to thank to several local experts for their recommendations. We also thank very much prof. A.F.G. Dixon for revising the language and two referees for their valuable comments. This research was supported by the grant No. CZ.1.05/1.1.00/02.0073 of the MSMT.

\section{REFERENCES}

Chytrý M, Kučera T, Kočí M (eds) (2001) Katalog biotopů České republiky. Interpretační př́ručka $\mathrm{k}$ evropským programům Natura 2000 a Smaragd. AOPK ČR, Praha. In Czech.

Chvátal M (ed.) (2009) Special Protection Areas of the Czech Republic. Agency for Nature Conservation and Landscape Protection in the Czech Rep. and Aventinum Publ. Prague.
European Commission (2012) Draft Wilderness Management Guidance Document for Natura 2000 managers, European Commission DG Environment.

Guth J (ed.) (2002) Metodiky mapování biotopů soustavy Natura 2000 a Smaragd. AOPK ČR, Praha. In Czech.

Hartel H, Lončíková J, Hošek M (eds) (2009) Mapování biotopů v České republice. Východiska, výsledky, perspektivy. AOPK ČR, Praha. In Czech with English summary.

Hußlein M, Kiener H (eds) (2007) Natura 2000 - Europas Wildes Herz / Divoké Srdce Evropy, Natura 2000 bilingual brochure. Grafenau/Vimperk.

Hußlein M, Kiener H, Křenová Z, Šolar M (eds) (2009) The appropriateness of non-intervention management for protected areas and Natura 2000 sites. Srni Conference Report. Grafenau/ Vimperk.

Kautz M, Dworschak K, Gruppe A, Schopf R (2011) Quantifying dispersal of bark beetle infestations in epidemic and non-epidemic conditions. Forest Ecol Manag 262: 598-608.

Kiener H, Hußlein M, Englmaier KH (2008) Natura 2000, Management in Nationalpark Bayrischer Wald.

Kř̀nová Z (2008) Kyrill a Natura 2000 v Národním parku Šumava. Ochrana prírody 1: 36-37.

Křenová Z, Hruška J (2012) Proper zonation - an essential tool for the future conservation of the Šumava National Park. Eur J Environ Sci 2: 62-72.

Křenová Z, Kiener H (2012) Europe's Wild Heart - still beating? Experiences from a new transboundary wilderness area in the middle of the old continent. Eur J Environ Sci 2: 115-124.

Lehnert LW, Bässler C, Brandl R, et al. (2013) Conservation value of forests attacked by bark beetles: Highest number of indicator species is found in early successional stages. J Nat Conserv 21: 97-104.

Müller J, Bußler H, Goßner M, et al. (2008) The European spruce bark beetle Ips typographus (L.) in a national park - from pest to keystone species. Biodivers Conserv 17: 2979-3001.

Sundeth K, Creed P (2009) Natura 2000. Ochrana biodiversity Evropy. Úřad pro úřední tisk ES, Lucemburk. In Czech, editions in other EU languages are available.

Šolar M, Galland P (2002) Sumava National Park (Czech Republic), Report of the IUCN / WCPA Mission 22-25 September 2002. 